\title{
Sense of safety among medical staff working in a psychiatric ward
}

\author{
Jakub Ciebiera ${ }^{1, A-D \oplus}$, Zbigniew Orzeł ${ }^{2, A, C, E \oplus}{ }^{\circ}$, Anna Włoszczak-Szubzda ${ }^{2,3, C, E-F \oplus}$, \\ Paulina Maria Kaczor-Szkodny ${ }^{3, C, E \odot}$ \\ ${ }^{1}$ Samodzielny Publiczny Wojewódzki Szpital Specjalistyczny w Chełmie, Polska \\ ${ }^{2}$ University of Economics and Innovation, Lublin, Poland \\ ${ }^{3}$ Institute of Rural Health, Lublin, Poland \\ A - Koncepcja i projekt badania, B - Gromadzenie i/lub zestawianie danych, C - Analiza i interpretacja danych, \\ D - Napisanie artykułu, E - Krytyczne zrecenzowanie artykułu, F - Zatwierdzenie ostatecznej wersji artykułu
}

Ciebiera J, Orzeł Z, Włoszczak-Szubzda A, Kaczor-Szkodny PM. Sense of safety among medical staff working in a psychiatric ward. Med Og Nauk Zdr. 2019; 25(3): 187-193. doi: 10.26444/monz/111255

\begin{abstract}
Introduction and objective. Acts of aggression and physical violence directed against medical staff decrease the sense of work safety, resulting in the depersonalisation and gradual departure of medical staff from the profession. The aim of the study was to investigate the sense of safety among medical staff employed in the psychiatric ward of a Polish provincial hospital.

Materials and method. The pilot study included 88 persons who represented various medical professions employed in a psychiatric ward of the Independent Public Provincial Specialist Hospital in Chełm, The discussed phenomenon was evaluated by a survey method, by means of an author-constructed questionnaire as a research instrument. Statistical analysis was conducted using statistical software SPSS.

Results. The majority of medical personnel working in the psychiatric ward in the Independent Public Province Specialist Hospital in Chełm reported that the work in the ward is associated with a low sense of safety. Only the respondents who had the lowest period of employment (less than 5 years) evaluated work in the psychiatric ward as safe. Those with the longest period of employment in the psychiatric ward felt less secure; simultaneously, the respondents' admitted that being on duty together with persons who had the longest period of employment was the safest. No statistically significant differences in the lack of the sense of safety at work in a psychiatric ward were observed according to gender.

Conclusions. Statistically significant differences were noted between respondents' opinions concerning their alleviating effect on releasing aggressive behaviours. Such an opinion was expressed mainly by paramedics.
\end{abstract}

\section{Key words}

nurse, sense of safety, psychiatric wards

\section{INTRODUCTION}

Aggression is a common phenomenon, it is an element of human life, and remains in the area of interest of many sciences, both natural sciences and the humanities. Many definitions of aggression are encountered in literature; however, there is no single coherent definition which would precisely specify the essence and scale of this phenomenon [1]. The scope of problems concerning the definition of aggression is considered on many levels, it is perceived, among other things, in the categories of biological, social and psychological sciences. According to biological concepts, aggression lies in human nature, and any manifestations of aggressive behaviours arose in the course of evolution, and are the pattern of behaviour which is necessary for the preservation of the species. Social concepts pertain to aggression arising from the environment, acquired and established at the stage of socialization in the family [2]. Psychology provides, among others, the concept of aggression consisting in the desire to control others; according to one of the definitions in psychology, aggression is a violent, belligerent, disruptive behaviour which causes harm to the victim [3].

Address for correspondence: Paulina Maria Kaczor-Szkodny, Institute of Rural Health, Lublin, Poland

E-mail: paulina.kaczor7@wp.pl

Received: 22 May 2019; Accepted: 25 July 2019; first published: 6 September 2019
Most frequently, aggression is defined as 'any act that harms another individual who is motivated to avoid such harm'. According to Buss (1961), aggression is 'a response that delivers noxious stimuli to another organism' [4], i.e. the behaviours which are undertaken with the intention to cause negative consequences. In literature, under the concept of 'aggression', the most frequently refer to any actions in which there occurs fear, frustration, or desire to evoke these emotions in others. In psychiatry, a very frequent form of aggression is self-aggression, i.e. the form of aggression directed by a patient against self [5]. Aggression is also manifested by acts of vandalism and violence directed against various forms of life (animals, plants, etc.).

The problem of aggression may be described in various ways, with each scientific domain establishing own theories concerning aggression, using many categories and typologies facilitating the precise specification of this phenomenon in own unique way. This short review of the concepts pertaining to aggression clearly demonstrates the difficulties encountered in dealing a substantive problem.

Aggression in psychiatric hospitals is a common everyday phenomenon. Escalation of the symptom of aggressive behaviour usually occurs during the initial period of hospitalization when, apart from the aggravation of the symptoms of mental disorders, there occur stressors connected with the limitation of privacy, and an excessive amount 
of stimuli from the environment. Patients with disorders perceive treatment as coercion, limitation of freedom, as well as a threat. Actions undertaken by medical staff with respect to a patient are perceived by the patient as depravation of the sense of impact on own life, which causes frustration. The factors which exacerbate aggressive behaviour are frequently related with non-professional behaviour and, in the opinion of a patient, provocative approach by the medical staff. Patients with mental disorders most often do not accept treatment, which they consider as harmful; additionally, the specificity of a psychiatric ward (bars on the windows, doors without handles, the use of means of coercion), enhance the effect of aggression. Thus, proper preparation of the medical staff is an extremely important factor, and special attention should be paid to the conditions in which there occurs the first contact with a patient. Very often, the factor connected with work overload and stress among the medical staff participates in the occurrence of the phenomenon of aggression, and in an unconscious way, transferred onto relations with a patient, and considerably enhances the symptoms of aggression on the part of the patient. Situational factors occurring during the first period of hospitalization, to the greatest degree, are responsible for the escalation of aggressive behaviours [6,7].

Factors related with exacerbation of aggressive behaviour may be divided into three sphere:

\section{1) Factors connected with medical staff:}

- attitude of an omniscient judge;

- use of an elevated, menacing tone of voice or body language;

- ignoring the needs of the patient, not listening to the patient, lack of understanding;

- not informing a patient about his/her state of health or communicating this information in an insufficient way;

- insufficient number of staff and lack of time;

- lack of skills of coping with own emotions, which are frequently transferred onto a patient (often in an unconscious way).

\section{2) Factors related with the environment:}

- restrictive hospital rules (designated visiting hours, surveillance, various types of treatment applied);

- adverse environment(e.g. dark, crowded rooms, high escalation of sounds);

- large number of persons;

- lack of privacy;

- unknown, alien environment;

- lack of principles related with the sense of safety.

\section{3) Factors related with a patient:}

- all factors associated with the mental and somatic state of a patient;

- current frustrating situation;

- behaviours which indicate the planning of aggressive behaviours (body posture, eye contact, psycho-motor hyperactivity, tone of voice);

- verbal announcements, threats [8;9].

The task of the medical staff is an early recognition of the risk factors of the occurrence of the act of aggression. In order to evaluate the possibilities of aggressive acts, the medical staff have at their disposal appropriate instruments for such an evaluation. The first of them is the Overt Aggression
Scale (OAS), which enables evaluation of aggression in its four forms: verbal, physical against objects, physical against others, and physical aggression against self. In addition, it contains 11 interventions which may be applied by the medical staff. The subsequent instrument for the measurement of aggression is the 11-point Social Dysfunction and Aggression Scale (SDAC), which also serves for the evaluation of aggressive mood and behaviours predisposing for aggressive behaviour. Together with the SDAS, the Staff Observation Aggression Scale (SOAS) may be used. These scales are helpful and reliable tools, which at the same time allow the distinction of various forms of aggression [10].

Stress and occupational burnout of medical staff in psychiatric hospitals. Work in the medical professions is burdened with high occupational risk. Every day, the employees encounter many negative bio-psychosocial factors exerting an effect on their status, all these elements being closely connected with the specificity of the profession practiced and specificity of the medical facility. Some specializations (including palliative care, psychiatry, oncology) are burdened with a greater load, and consequently with an increased level of stress; in facilities of this type the staff are additionally exposed to violence and aggression on the part of patients, and often also on the part of patients' families. This causes a considerable load on the organism, which is often translated into the quality of work, is related with occupational burnout, and, in consequence, results in resignation from the profession practiced [11].

Psychiatric wards are among the most specific medical facilities, where the work is associated with high stress due to the occupation performed. Work in a facility of this type is connected with higher exposure to stressful situations considering an increased amount of stress-inducing factors. The commonly occurring problem of aggression should be considered as the main cause of stress which affects medical staff employed in a psychiatric ward (88\%, according to the study conducted by E. Rejek and M. Szmigiel). For the medical staff taking care of a patient with mental disorders the risk of stress is somehow inscribed in the occupational risk.

Despite legal regulations describing the principles of management of aggressive patients, ultimately there are no specified guidelines concerning routines in the situation of exposure to behaviour on the part of a patient with mental disorders. According to the study conducted by Erdos and Hughes, the reporting rate of such incidents is only 5\% [11]. The staff of psychiatric facilities deal every day with various hazards on the part of patients. The risk of committing suicide by a patient constitutes a special psychological burden, as well as treating patients with mental disorders against their will, use of coercive means, and the necessity of violating the intimacy of own patients in the matter of family affairs. The specificity of a psychiatric ward concerns not only pathological symptoms, but also quick and appropriate response to various situations, the necessity to make decisions for a patient, constant surveillance, as well as the skill of taking control over patients who often break internal rules of procedure.

In many publications concerning the practicing of medical professions it is stated that specificity of work in psychiatric wards belongs to those which cause the greatest psychological load. The quality of work, interpersonal relations at the workplace, and aggressiveness of patients are the main 
problems for the medical staff who are exposed to these factors every day. All this, at a very fast rate leads to occupational burnout. The main factors indicating the beginning of the process of depersonalization include: discontinuation of taking satisfaction from work and life, deterioration of interpersonal relationships which, in consequence, leads to the deterioration of the quality of work [6].

In Poland, similar to many countries worldwide, a serious shortage of staff is observed among psychiatric personnel, especially with respect to psychiatric nurses. There is also a lack of greater interest and any stimuli encouraging undertaking work in this area. This results from the lack of encouragement for undertaking this work, lack of safety, as well as social stigma associated with mental diseases in general. In order to provide an appropriate number of well-qualified staff, first of all, it is necessary to create a safe workplace, develop effective strategies for recruitment, and resigning from work by medical psychiatric staff, with adequate support on the part of units responsible for employment policy.

A very important and constantly omitted issue is the provision of support for persons already performing the occupation, including, among others, access to psychological care, content support, possibility of further professional development, and improvement of the skill which has already been acquired. The key issue is a proper approach to the problem of occupational burnout in psychiatric care. Among the factors which facilitate the process of occupational burnout in this occupational group, is primarily the problem of work safety and occupational hygiene, and, which is most important, the problem of the risk of exposure to aggression and violence experienced on the part of patients. All these factors exert a direct effect on recruitment and resignation from the job by medical staff, and affect the decision of the future employees/students concerning the choice of future specialization [12].

\section{OBJECTIVE}

The aim of the study was investigation of the state of the sense of safety among medical staff employed in the psychiatric ward of a provincial hospital in Poland.

\section{MATERIALS AND METHOD}

A representative group of employees in a psychiatric ward at a provincial hospital in the Lublin Region was selected for the needs of the presented study. A non-random sampling method was applied. In consideration of the fact that the study concerned a specified population, the size of the sample was 88 persons. The study was conducted during the period 21 April - 5 May 2018. The questionnaires were completed personally, after previous expression of informed consent by the respondents. The respondents were informed concerning voluntary participation and anonymity of the conducted questionnaire.

In the study group, females prevailed (55\%); males constituted $45 \%$ of the total number of respondents. The largest number of respondents performed the occupation of a nurse (55\%); $27 \%$ of the total number of medical staff employed in the psychiatric ward were employed at the workplace of a doctor/psychologist, whereas $18 \%$ of the total number of respondents performed the job of a paramedic. Analysis of the respondents' period of employment indicated that about forty percent of people had practiced the profession for more than 20 years, while a slightly smaller group had a period of employment between $10-20$ years (31\%). Those who had performed the occupation for 5-10 years constituted $9 \%$ of the study group, whereas those with a period of employment of less than 5 years $-18 \%$ of the respondents.

The research method applied was a survey and the method of field research used an author-constructed questionnaire consisting of 21 items. The questions in the questionnaire included problems pertaining to manifestations of aggression on the part of patients experienced by the employees of the Psychiatric Ward in Chełm, and their state of the sense of safety associate with it. While constructing the questionnaire, closed questions were primarily used, as well as open questions which enabled the respondents to speak freely. Within the basic standardization of the research instrument, a pilot study was conducted. A questionnaire was distributed among 10 persons employed at medical workplaces in the psychiatric ward in Chełm, with the request to complete it, and also provide their remarks. After analysis of the information collected based on the pilot study, the questionnaire items did not change.

Statistical analysis of the collected data was performed using the software IBM SPSS. Subsequently, percentages were calculated from the compiled results. Statistical relationships were calculated using cross-tables, and non-parametric Pearson's chi-square goodness-of-fit test. The p values $\mathrm{p}<0.05$ were considered statistically significant.

A dependent variable was selected and independent variables with indicator:

- dependent variable - safety in a psychiatric ward,

- independent variables:

gender indicators: male, female,

period of employment indicators:

- up to 5 years;

- from 5-10 years;

- from 10-20 years;

- for more than 20 years;

profession practiced indicators:

- nurse;

- doctor;

- psychologist;

- paramedic.

\section{RESULTS}

The first analysis concerned an evaluation of work safety in a psychiatric ward; several study groups were distinguished; the category of division was medical profession practiced. The results of the study were as follows:

- 66 of the respondents did not feel secure in the psychiatric ward, including: doctors/psychologists - 22 (91.7\%), nurses $34(70.8 \%)$, and medial orderlies -10 respondents $(62.5 \%)$, - 22 respondents when asked about their sense of safety reported that they feel safe at work in the psychiatric ward, including: doctors/psychologists 2 (8.3\%), nurses $14(29.2 \%)$, and paramedics 6 (37.5\%) (Tab. 1 and 1a).

The analysis presented below presents the investigation conducted from the aspect of the effect of period of 
Table 1. Evaluation of work safety and profession practiced

\begin{tabular}{lcccc}
\hline \multirow{2}{*}{ Profession } & \multicolumn{4}{c}{ Evaluation of work safety } \\
\cline { 2 - 5 } doctor/psychologist & Numbers & No & Yes & Total \\
\cline { 2 - 5 } & $\mathrm{N}$ & 22 & 2 & 24 \\
\hline \multirow{2}{*}{ nurse } & $\%$ & 91.70 & 8.30 & 100 \\
\hline \multirow{2}{*}{ paramedic } & $\mathrm{N}$ & 34 & 14 & 48 \\
\hline \multirow{2}{*}{ Total } & $\mathrm{N}$ & 70.80 & 29.20 & 100 \\
\cline { 2 - 5 } & $\%$ & 62.50 & 37.5 & 100 \\
\hline
\end{tabular}

Source: own study

Table 1a. Evaluation of work safety and profession practiced

\begin{tabular}{lccc}
\hline & Value & Df & Asymptotic Significance (2 Sided) \\
\hline Pearson's chi-square & $5.333^{\mathrm{a}}$ & 2 & 0.069 \\
\hline Likelihood ratio & 6.084 & 2 & 0.048 \\
\hline N relevant observations & 88 & & \\
\hline
\end{tabular}

Source: own study.

a 1 cells $(16.7 \%)$ have expected count less than 5 . The minimum expected count is 4.00 .

employment of the respondents employed in the psychiatric ward on their sense of work safety. The following results of the study were obtained:

- the group of respondents who had a period of employment in the psychiatric ward less than 5 years included 16 persons, of whom $5(31.3 \%)$ replied that work in a psychiatric ward may be considered as unsafe, while 11 (68.8\%) considered work in this ward as safe;

- the group of respondents with the period of employment between 5-10 years was the smallest, and consisted of 8 persons, 7 of whom evaluated work in a psychiatric ward as unsafe (87.5\%), and only $1(12.5 \%)$ as safe;

- the group of respondents who had a period of employment between 10-20 years included 27 persons, 24 of them (88.9\%) considered work as unsafe, and $3(11.1 \%)$ respondents as safe;

- The last study group were respondents with a period of employment of more than 20 years, and included 37 persons, 30 of whom $(81.1 \%)$ considered work in a psychiatric ward as unsafe, while 7 respondents (18.9\%) as safe (Tab. 2 and $2 a)$. The result proved to be highly significant statistically $-\mathrm{p}=0.000$.

The subsequent analysis concerned the assumption that work together with a co-worker who has a longer period of employment improves the sense of safety at work. The results of the study showed the following:

- the group of respondents who had a period of employment in the psychiatric ward less than 5 years included 16 persons, $9(56,3 \%)$ of whom considered that a longer period of employment of their co-worker improves their sense of safety, while 2 (12.5\%) had no opinion, and 5 (31.3\%) respondents provided a negative answer;

- the study group of employees who had practiced the profession for a period between 5-10 years included 8 respondents, $3(37.5 \%)$ of them admitted that a longer period of employment of their co-worker improved their sense of safety, $3(37,5 \%)$ had no opinion, whereas $2(25.0 \%)$ respondents provided a negative answer;
Table 2. Sense of safety and period of employment

\begin{tabular}{lcccc}
\hline \multirow{2}{*}{ Period of employment } & \multicolumn{5}{c}{ Sense of safety } \\
\cline { 2 - 5 } between $10-20$ years & Numbers & No & Yes & Total \\
\hline \multirow{2}{*}{ between $5-10$ years } & $\mathbf{N}$ & 24 & 3 & 27 \\
\hline \multirow{2}{*}{ less than 5 years } & $\mathbf{N}$ & 7 & 1 & 8 \\
\hline \multirow{2}{*}{ more than 20 years } & $\%$ & 87.50 & 12.50 & 100 \\
\hline \multirow{2}{*}{ Total } & $\mathbf{N}$ & 5 & 11 & 16 \\
\cline { 2 - 5 } & $\mathbf{N}$ & 31.30 & 68.70 & 100 \\
\hline & $\%$ & 30 & 7 & 37 \\
\hline
\end{tabular}

Source:own study.

Table 2a. Sense of safety and period of employment

\begin{tabular}{lccc}
\hline & Value & Df & Asymptotic Significance (2 Sided) \\
\hline Pearson's chi-square & $20,508^{\mathrm{a}}$ & 3 & 0,000 \\
\hline Likelihood ratio & 18,338 & 3 & 0,000 \\
\hline N relevant observations & 88 & &
\end{tabular}

2 cells $(25 \%)$ have expected count less than 5 . The minimum expected count is 2.00 . Source:own study.

- the study group with a period of employment between 10-20 years consisted of 27 respondents, 14 (51.9\%) of them mentioned that the period of employment of their co-worker had an effect on their sense of safety, 7(25.9\%) respondents had no opinion, while $6(22.2 \%)$ respondents provided a negative answer;

- the study group of respondents who had a period of employment longer than 20 years included 37 persons, 23 (62, $2 \%)$ of whom reported that while being on duty together with a person with a longer period of employment they felt more secure, $8(21.6 \%)$ respondents had no opinion concerning this problem, whereas $6(16,2 \%)$ respondents considered that it did not improve their sense of safety (Tab. 3 and $3 a$ ).

Table 3. Staffing on duty according to period of employment and sense of safety

\begin{tabular}{|c|c|c|c|c|c|c|}
\hline \multirow{10}{*}{$\begin{array}{l}\text { Staffing } \\
\text { on duty } \\
\text { according } \\
\text { to period of } \\
\text { employment }\end{array}$} & & \multirow[b]{2}{*}{ Numbers } & \multicolumn{4}{|c|}{ Sense of safety } \\
\hline & & & No & $\begin{array}{l}\text { I do not } \\
\text { know }\end{array}$ & Yes & Total \\
\hline & \multirow{2}{*}{$\begin{array}{l}\text { between } \\
10-20 \text { years }\end{array}$} & $\mathrm{N}$ & 6 & 7 & 14 & 27 \\
\hline & & $\%$ & 22.20 & 25.90 & 51.90 & 100 \\
\hline & \multirow{2}{*}{$\begin{array}{l}\text { between } \\
5-10 \text { years }\end{array}$} & $\mathbf{N}$ & 2 & 3 & 3 & 8 \\
\hline & & $\%$ & 25.00 & 37.50 & 37.50 & 100 \\
\hline & \multirow{2}{*}{$\begin{array}{l}\text { less than } \\
5 \text { years }\end{array}$} & $\mathbf{N}$ & 5 & 2 & 9 & 16 \\
\hline & & $\%$ & 31.30 & 12.50 & 56.30 & 100 \\
\hline & \multirow{2}{*}{$\begin{array}{l}\text { more } \\
\text { than } 20\end{array}$} & $\mathbf{N}$ & 6 & 8 & 23 & 37 \\
\hline & & $\%$ & 16.20 & 21.60 & 62.20 & 100 \\
\hline \multirow{2}{*}{ Total } & & $\mathbf{N}$ & 19 & 20 & 49 & 88 \\
\hline & & $\%$ & 21.60 & 22.70 & 55.70 & 100 \\
\hline
\end{tabular}

Source: own study. 
Table 3a. Staffing on duty according to period of employment and sense of safety

\begin{tabular}{lccc}
\hline & Value & Df & Asymptotic Significance (2 Sided) \\
\hline Pearson's chi-square & $3.707 a$ & 6 & 0.716 \\
\hline Likelihood ratio & 3.733 & 6 & 0.713 \\
\hline N relevant observations & 88 & & \\
\hline
\end{tabular}

5 cells $(41.7 \%)$ have expected count less than 5 . The minimum expected count is 1.73 . Source:own study.

The result was statistically insignificant $-\mathrm{p}=0.716>0.05$

The subsequent analysis concerned the sense of safety at work in a psychiatric ward according to the employee's gender; 38 (57.6\%) females and 28 (42.4\%) males admitted that work in a psychiatric hospital is unsafe; 22 respondents evaluated work in a psychiatric hospital as safe, including 10 (20.8\%) females, and 12 (30\%) males (Tab. 4 and $4 a$ ).

Table 4. Work in a psychiatric hospital and sense of safety according to gender

\begin{tabular}{lcccc}
\hline \multirow{2}{*}{ Gender } & \multicolumn{4}{c}{ Work safety } \\
\cline { 2 - 5 } Females & Numbers & No & Yes & Total \\
\hline \multirow{2}{*}{ Males } & $\mathbf{N}$ & 38 & 10 & 48 \\
\cline { 2 - 5 } & $\mathbf{\%}$ & $79.20 \%$ & $20.80 \%$ & $100.00 \%$ \\
\hline \multirow{2}{*}{ Total } & $\mathbf{N}$ & 28 & 12 & 40 \\
\hline & $\mathbf{N}$ & $70.00 \%$ & $30.00 \%$ & $100.00 \%$ \\
\hline
\end{tabular}

Source: own study.

Table 4a. Work in a psychiatric hospital and sense of safety according to gender

\begin{tabular}{|c|c|c|c|c|c|}
\hline & Value & df & $\begin{array}{l}\text { Asymptotic } \\
\text { Significance } \\
\text { (2 Sided) }\end{array}$ & $\begin{array}{c}\text { Exact } \\
\text { Significance } \\
\text { (2-sided) }\end{array}$ & $\begin{array}{c}\text { Exact } \\
\text { Significance } \\
\text { (1-sided) }\end{array}$ \\
\hline Pearson's chi-square & $0.978^{a}$ & 1 & 0.323 & & \\
\hline Continuity correction $^{b}$ & 0.55 & 1 & 0.458 & & \\
\hline Likelihood ratio & 0.975 & 1 & 0.323 & & \\
\hline Fisher exact test & & & & 0.337 & 0.229 \\
\hline $\begin{array}{l}\mathrm{N} \text { relevant } \\
\text { observations }\end{array}$ & 88 & & & & \\
\hline
\end{tabular}

a 0 cells $(0.0 \%)$ have expected count less than 5 . The minimum expected count is 10.00 ${ }^{\mathrm{b}}$ Calculated exclusively for Table $2 \times 2$ Source: own study.

The study result was statistically insignificant because $\mathrm{p}=0.323>0.05$.

The study below concerned the situation when respondents witnessed to aggression on the part of patients. The respondents were asked whether their presence exerted a positive effect on the alleviation of the conflict. The total number of respondents who participated in the study 88 (100.0\%), were divided into study groups according to the period of employment. Based on the collected research material the following results were obtained:

- in the study group doctor/psychologist - 5 (20.8\%) respondents provided a positive answer, whereas 19 (79.2\%) a negative answer;

- in the study group nurses - $16(33.3 \%)$ respondents provided a positive answer, while $32(66.7 \%)$ a negative answer.
- in the study group paramedic - $11(68.8 \%)$ respondents provided a positive answer, whereas $5(31.3 \%)$ a negative answer (Fig. 1 and Tab. 5a).

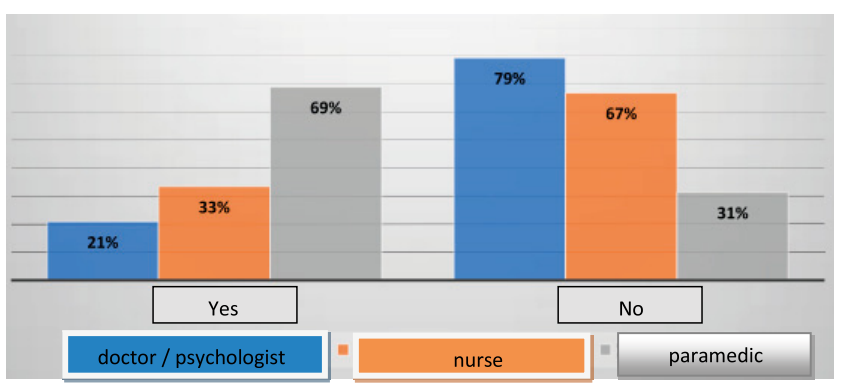

Figure 1. Skills of medical staff to alleviate conflicts among patients respondents'opinions.

Source: own study.

Table 5a. Skills of medical staff to alleviate conflicts among patients respondents' opinions

\begin{tabular}{lccc}
\hline & Value & Df & Asymptotic Significance (2 Sided) \\
\hline Pearson's chi-square & $9.944^{\mathrm{a}}$ & 2 & 0.007 \\
\hline Likelihood ratio & 9.821 & 2 & 0.007 \\
\hline N relevant observations & 88 & & \\
\hline
\end{tabular}

a 0 cells $(0.0 \%)$ have expected count less than 5 . The minimum expected count is 5.82 . Source: own study.

The study results were statistically significant because $\mathrm{p}=0.007>0.05$.

\section{DISCUSSION}

Work safety is an important aspect while performing medical professions, because it exerts a direct effect on the quality of work and the quality of medical care. However, this problem has been sporadically undertaken in scientific publications. Statistical data demonstrate that the number of persons suffering from various types of mental disorders is constantly increasing $[13,14,15]$. Nevertheless, the disease never occurs independently, and is almost always related with certain consequences, in the case of mental diseases and disorders one of the side-effects appears in the form of aggression, and related with it lack of the sense of safety. Analysis of the available scientific reports concerning the occurrence of the acts of aggression shows that there is a lack of unequivocal data based on which it would be possible to evaluate the scale of occurrence of this phenomenon in Poland. On the website of the Panoptykon Foundation, which refers to data from the System of Monitoring Aggression in Health Care over the period of the last two years, 94 officially reported cases were registered concerning aggressive behaviours with respect to medical staff $[16,17,18]$. However, the study by Markiewicz R. (2012) pertaining to the manifestations of aggression against psychiatric nursing staff showed that $78 \%$ of them experienced physical aggression, while $35 \%$ in the form of verbal aggression $[19,20]$. In the study by Berent D. (2009), more than a half of nurses declared that while performing their occupational duties they had encountered the phenomenon of aggression every day.

The above-mentioned data confirm that aggression is a frequent, almost everyday phenomenon; however, the 
undesirable events including aggressive behaviour of patients are infrequently officially reported. The data presented above illustrate the extent of the phenomenon of aggression, which is reflected in the sense of safety at work.

In the study by D. Berent in the Admission Department at the Psychiatric Hospital, Independent Public Health Care Unit in Rybnik, south-west Poland, medical staff were asked about the sense of safety at work. The majority of respondents reported that they considered their work as safe; however, when asked to assess safety according o the scale from 1-6, where 1 was unsafe and 6 very safe, none of these respondents indicated more than 3 scores $[21,21]$; similar results were obtained in own study.

The problem of aggression with respect to medical staff still remains an unsolved problem, because there are no guidelines, directives, or good practices in the area of counteracting and prevention of the occurrence of this phenomenon. Considering the fact that this is a common problem, the EU has still not undertaken steps aimed at formulating standards of management in such cases which would be common for all member countries [23].

In the study conducted in 2,809 medical staff from 17 countries, among whom employees of psychiatric wards constituted $54 \%$ of the population, an evaluation was performed of the management of violence. Unfortunately, as shown by the results of investigations, in almost $1 / 5$ of respondents (19.5\%), no trainings in this area had been carried out. In the situation of threat, the employees most often applied physical constraint of aggressive patients, keeping them in isolation, or pharmacotherapy. Educational shortages in the area of prevention of violence, or assessment of risk or factors inducing violence and aggression in patients, may be considered as a cause of the lack of decreased feeling of safety among medical staff [23].

The manifestations of aggression among patients most frequently encountered by the staff of psychiatric wards are verbal violence (88.1\%), and physical violence (58.4\%). According to research and taking into account the character of psychiatric wards, the nursing staff most often struggle with violence and aggression on the part of patients, which exerts a considerable effect on the level of experienced occupational stress and life satisfaction $[24,25]$. The level of the sense of safety and life satisfaction is a direct reflection of relationships between the staff of psychiatric wards and patients.

Mutual expectations, both on the part of the medical staff and patients, may intensify the problem. The sense of a relative and mutual understanding shapes the staffpatient relationship in a positive or negative way. The lack of sympathetic and competent care intensifies the negative reception and the image of relations [26]. A study conducted among 119 patients in an acute psychiatric ward, duties, as well as availability, communicativeness, engagement, or therapeutic environment in the wards, considerably affected the perception of the staff of these wards and attitudes towards them. The factors negatively perceived by patients, which may additionally affect their behaviours, is declared in studies, the unwillingness of the staff towards patients, hostility, impulsiveness, and frustration, and a specific helplessness, as well as poor communication and incoherence of care [27].

Another factor exerting an effect on the level of aggression and violence with respect to medical staff is the type of ward. Analysis of a 15-year period of the functioning of 21 German psychiatric hospitals showed that no differences were observed in the forms of aggression occurring in closed and open wards; however, in open wards, the necessity for carrying out interventions to control aggressive behaviours was significantly lower [28].

The discussion referred mainly to the studies conducted in this area in Poland; nevertheless, footnotes contain references to similar studies conducted worldwide.

\section{CONCLUSIONS}

The conducted study and analyses of results allowed the following final conclusions to be made:

1. The vast majority of the staff employed in the psychiatric ward in the Independent Public Province Specialist Hospital in Chełm, expressed the opinion that work in a psychiatric ward is associated with a low sense of safety.

2. Only the respondents with the shortest period of employment (less than 5 years) - most of them evaluated work in a psychiatric ward as safe.

3. Respondents with the longest period of employment in a psychiatric ward felt the least secure; at the same time, being on duty together with a person who has the longest period of employment was evaluated by the respondents as the safest.

4. No statistically significant differences in the lack of the sense of safety at work in a psychiatric ward were observed according to the respondents' gender.

5. In turn, the respondents' evaluation of their alleviating effect on releasing aggressive behaviours was statistically significant. Such an opinion was expressed by the majority of paramedics.

\section{Postulated conclusions.}

1) Periodical trainings in management of conflict situations and skills of cooping in conflict situations.

2) Periodical trainings in interpersonal communication with a patient, patient's family, and other medical staff.

3) Creation of peer-support groups for psychiatric medical staff directly in the ward.

4) Individual work of medical staff with a psychologist/psychotherapist employed in a psychiatric ward.

5) Constant monitoring, documentation and analysis of conflict situations which end with physical aggression, and analysis of how these situations may be avoided in the future.

6) Constant monitoring, documentation and analysis of conflict situations which end with verbal aggression, and analysis of how these situations may be avoided in the future.

\section{REFERENCES}

1. Borzucka-Sitkiewicz K. Środowiskowe uwarunkowania agresywnych zachowań młodzieży (Environmental determinants of aggressive behavior of young people). Wydawnictwo Uniwersytetu Śląskiego, Katowice; 2010: 13 .

2. Bjørkly S. Psychological theories of aggression: principles and application to practice. [in] Richter D, Whittington R. Violence in Mental Health Settings: Causes, Consequences, Management. Springer 2016: 27-46.

3. Benjamin AJ. Aggression. [in] Friedman H. Encyclopedia of Mental Health, Volume 1, Edition: 2, Chapter: Aggression, Publisher: Academic Press, 2015: 33-39.

4. Kowalczuk K, Jankowiak B, Krajewska-Kułak E, Rolka H, Sierakowska M. Teoria agresji - prawda czy mity? (Theories of aggression - reality or myths?). Problemy Pielęgniarstwa 2011; 19(3): 396-400. 
5. Kacpeska MJ. Samookaleczanie się a autoagresja i depresja (Self-harm versus auto aggression and depression). http://www.psychiatria.pl/ artykul/samookaleczanie-sie-a-autoagresja-i-depresja/18520 (access: 15.04.2018).

6. Mosiołek A, Koweszko T, Gierus J. Agresja w placówkach psychiatrycznych - próba zdefiniowania problemu (Aggression in psychiatric institutions - an attempt to define the problem). Psychiatria. 2014; 11(2): 87-91.

7. Iozzino L, Ferrari C, Large M, Nielssen O, de Girolamo G. Prevalence and risk factors of violence by psychiatric acute inpatients: a systematic review and meta-analysis. PLoS One 2015; 10: e0128536.

8. Kliś A. Profilaktyka agresji i przemocy u pacjentów w ośrodkach dializ (Prophylaxis of patients' aggression and violence in dialysis centres). Forum Nefrologiczne. 2011; 4(2): 177-182.

9. Abderhalden C, Needham I, Dassen T, Halfens R, Haug H-J, Fischer JE. Structured risk assessment and violence in acute psychiatric wards: randomised controlled trial. Br J Psychiatry 2008; 193: 44-50.

10. Rymaszewska J. Postępowanie z pacjentem agresywnym i pobudzonym (The proceeding if of an aggressive and agitated patient). Psychiatria w praktyce klinicznej. 2008; 1(2): 74-81.

11. Rejek E, Szmigiel M. Stres personelu związany ze specyfiką pracy na oddziale psychiatrycznym (Stress of medical personel related to specyfic work inthe psychiatric ward). Problemy Pielęgniarstwa 2016; 23(4): 515-519. doi:10.5603/PP.2015.0084.

12. Tsirigotis K, Gruszczyński W, Tokarska I. Zaburzenia nerwicowe u pielęgniarek oddziałów psychiatrycznych (Neurotic disorders of nurses in psychiatric hospital wards). Problemy Pielęgniarstwa 2011; 18(4): 461-468.

13. Usher K, Grigg M. Problem zasobów ludzkich (The problem of human resources). [in]: Wilczek-Różycka E, Kilańska D, Hajduk A. Pielęgniarstwo psychiatryczne. Problemy i kierunki rozwoju (Mental Health Nursing. Trends and issues). Szczecin: Wydawnictwo Copyright; 2010: 36-39.

14. Haines A, Brown A, McCabe R, Rogerson M, Whittington R. Factors impacting perceived safety among staff working on mental health wards. B J Psych Open. 2017; 3(5): 204-211.

15. Rymaszewska J, Adamowski T, Pawłowski T, Klejna A. Rozpowszechnienie zaburzeń psychicznych - przegląd ważniejszych badań epidemiologicznych (Prevalence of mental disorders - a review of major epidemiological studies). Postępy Psychiatrii i Neurologii. 2005; 14(3): 195-200.

16. Bowers L, Stewart D, Papadopoulos C, Dack C, Ross J, Khanom H, et al. Inpatient Violence and Aggression: A Literature Review. Section of Mental Health Nursing, Health Service and Population Research, Institute of Psychiatry, King's College London, 2011.

17. Gubernat B. Agresywny pacjent monitorowany (Monitoring aggressive patient). https://panoptykon.org/wiadomosc/agresywny-pacjentmonitorowany (access: 25.01.2019).

18. Laiho T, Lindberg N, Joffe G, Putkonen H, Hottinen A, Kontio R, et al. Psychiatric staff on the wards does not share attitudes on aggression. Int J Ment Health Syst. 2014; 8: 1-7.

19. Markiewicz R. Zachowania agresywne pacjentów wobec personelu pielęgniarskiego zatrudnionego w oddziałach psychiatrycznych (Aggressive behavior of patients towards nurse personnel employed in psychiatric wards). Curr Problem Psychiatry. 2012; 13(2): 93-97.

20. Nijman H, Bowers L, Oud N, Jansen G. Psychiatric nurses' experiences with inpatient aggression. Aggress Behav. 2005a;31: 217-27.

21. Berent D, i in. Agresja pacjentów wobec personelu medycznego Izby Przyjęć Szpitala Psychiatrycznego (Patients' aggression towards medical staff on admission to psychiatric hospital). Psychiatria i Psychoterapia. 2009; 5, 1-2 (2): 13-28.

22. Erickson L, Williams-Evans SA. Attitudes of emergency nurses regarding patient assaults. J Emerg Nurs. 2000; 26: 210-5.

23. Cowman S, Björkdahl A, Clarke E, Gethin G, Maguire J, European Violence in Psychiatry Research Group (EViPRG). A descriptive survey study of violence management and priorities among psychiatric staff in mental health services, across seventeen european countries. 2017; BMC Health Services Research BMC series - open

24. Itzhaki M, Peles-Bortz A, Kostistky H, Barnoy D, Filshtinsky V, Bluvstein I. Exposure of mental health nurses to violence associated with job stress, life satisfaction, staff resilience, and post囚traumatic growth. Int J Mental Health Nurs. 2015; 24: 403-412

25. Itzhaki M, Bluvstein I, Peles-Bortz A, Kostistky H, Bar Noy D, Filshtinsky V, Theilla M. Mental Health Nurse's Exposure to Workplace Violence Leads to Job Stress, Which Leads to Reduced Professional Quality of Life, Front. Psychiatry. 2018; 9: 59

26. Wiechula R, Conroy T, Kitson AL, Marshall RJ, Whitaker N, Rasmussen P. Umbrella review of the evidence: what factors influence the caring relationship between a nurse and patient? J Adv Nurs. 2016; 72(4): $723-734$

27. Stewart D, Burrow H, Duckworth A, Dhillon J, Fife S, Kelly S, MarshPicksley S, Massey E, O’Sullivan J, Qureshi M, Wright S, Bowers L. Thematic analysis of psychiatric patients' perceptions of nursing staff. Int J Mental Health Nurs. 2015; 24: 82-90.

28. Schneeberger AR, et al. Aggression and violence in psychiatric hospitals with and withoutopen door policies: A 15-year naturalistic observational study. J Psychiatric Res. 2017; 95: 189-195.

\title{
Poczucie bezpieczeństwa personelu medycznego pracującego na oddziale psychiatrycznym
}

\author{
I Streszczenie \\ Cel pracy. Akty agresji i przemocy fizycznej skierowane do personelu medycznego obniżają poczucie bezpieczeństwa \\ pracy, czego konsekwencją jest depersonalizacja oraz stopniowe odchodzenie z zawodu pracowników personelu medycz- \\ nego. Praca miała na celu zbadanie stanu poczucia bezpieczeństwa personelu medycznego zatrudnionego na oddziałach \\ psychiatrii. \\ Materiał i metody. Badaniem objęto 88 osób pracujących w Samodzielnym Publicznym Wojewódzkim Szpitalu Specja- \\ listycznym (SPWSzS) w Chełmie na oddziale psychiatrii, na różnych stanowiskach, w różnych zawodach medycznych. Do \\ oceny omawianego zjawiska zastosowano metodę sondażową oraz metodę badań terenowych, posłużono się narzędziem \\ badawczym, którym był autorski kwestionariusz ankiety. Analiza statystyczna została przeprowadzona z pomocą pakietu \\ statystycznego SPSS. \\ Wyniki.Zdecydowana większość osób zatrudnionych na oddziale psychiatrii w Samodzielnym Publicznym Wojewódzkim \\ Szpitalu specjalistycznym w Chełmie wyraziła opinię, że praca na oddziale psychiatrii wiąże się z niskim poczuciem bez- \\ pieczeństwa. Tylko ankietowani z najkrótszym stażem pracy (poniżej 5 lat) oceniali w większości pracę na oddziale psy- \\ chiatrycznym jako bezpieczną. Osoby z najdłuższym stażem pracy czuły się najmniej bezpiecznie, jednocześnie pełnienie \\ wspólnego dyżuru z osobami o najdłuższym stażu pracy ankietowani ocenili jako najbezpieczniejsze. \\ Wnioski. Braku poczucia bezpieczeństwa w pracy na oddziale psychiatrycznym nie różnicowała istotnie statystycznie \\ płeć respondentów. Wysoce istotna statystycznie była za to ocena respondentów na temat ich łagodzącego wpływu na \\ pacjentów, przejawiającego się rozładowywaniem agresywnych zachowań. Takie poczucie mieli w większości sanitariusze.
}

\section{Słowa kluczowe}

pielęgniarka/pielęgniarz, poczucie bezpieczeństwa, oddziały psychiatryczne 